\title{
Study on the Effect of Smart Pickup Box Service Quality on Customer's Use Intention Based on Technology Acceptance Model
}

\author{
Junxiu Zhang \\ College of Management \\ Wuhan University of Science and Technology \\ Wuhan, China \\ 1481104807@qq.com
}

\author{
Zeping Tong \\ College of Management \\ Wuhan University of Science and Technology \\ Wuhan, China \\ Tongzp76@126.com
}

\begin{abstract}
Smart Pickup Boxes (SPBs) have appeared in China for more than four years. To investigate the effect of the service quality the SPBs provide on the intention of use from the perspective of potential users, a theoretical model is proposed, based on technology acceptance model. We conducted a survey at schools, various districts, office buildings and other places. The statistic results show that (1) convenience has the strongest effect on perceived ease of use, perceived usefulness and customer's use intention; (2) perceived ease of use and perceived usefulness have significant effect on customer 's use intention; (3) perceived ease of use has positive effect on the perceived usefulness. The findings have implication on how to improve the intention of using SPBs.
\end{abstract}

Keywords-Smart Pickup Box; Servie Quality; Use Intention; Technology Acceptance Model(TAM)

\section{INTRODUCTION}

In recent years, with the rapid development of e-commerce, express companies are burgeoning too, while the "last mile" distribution problem has become the bottleneck of express development. In order to solve the problem of terminal logistics distribution, online retailers and express companies have made lots of attempts such as rookie station and convenience store, While the effect is not obvious. People begin to explore new solutions that can better solve the problem of terminal distribution, smart pickup boxes are produced based on the current embarrassment.

the smart pickup boxes have appeared in china for more than four years, while its utilization rate is not high. And smart pickup boxes expose some problems in the actual operation process, for example, the direction of development is fuzzy; the size and number is limited; the charge is non- standard. Due to the above problems, consumer satisfaction of the quality of the smart pickup box service has gone down, which not only can't solve the problem of terminal distribution, but lead to more potential problems, So that the development of smart pickup box loses its value. Therefore, the paper studies the effect of the service quality the SPBs provide on the intention of use from the perspective of potential users, which has significant contributions to solve the problem of the development of the smart pickup box and the "last mile" distribution

\section{LITERATURE REVIEW}

At present, the relevant researches on smart pickup box are mainly focused on the location and layout; the analysis of the feasibility and necessity; the present situation analysis of the overall development. However, the research on the service quality of the smart pickup box is almost not involved.

The Technology Acceptance Model was proposed by Davis when he applied the rational behavior theory to study the user's acceptance on the information system. The Technology Acceptance Model includes two main determinants: perceived usefulness and perceived ease of use, The original model of TAM is shown in Fig.1.

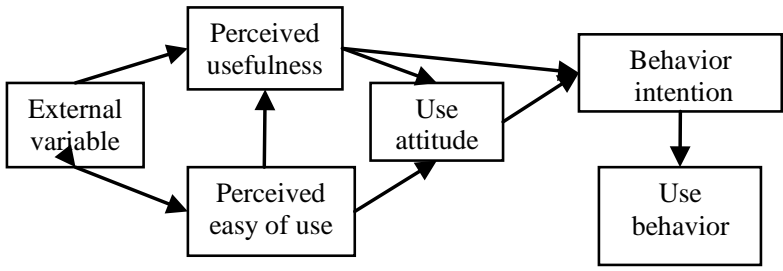

Fig. 1. TAM model

At present, the Technology Acceptance Model has been applied in many fields. According to the relevant researches[12 ], it can be seen that technology acceptance model is mainly used to study the effect of external variables on customer attitudes and customer's use intention. Most scholars built a own model on the basis of technology acceptance model, Therefore, the paper ,based on the technology acceptance model , combines with the characteristics of smart pickup box to build a theoretical model.

\section{RESEARCH HyPOTHESES AND MODEL CONSTRUCTION}

\section{A. Research hypotheses}

In this study, the service quality of the smart pickup box is a kind of subjective cognition, which is the comparison between perceived quality and expected quality. The service quality of the smart pickup box has three basic dimensions: convenience, diversity and responsiveness. Perceived usefulness means that customers think using the smart pickup box is useful for them. Perceived ease of use means that customers think grasping usage method of the smart pickup 
box is easy. The customer's use intention means the possibility that customers use the service that the smart pickup boxes provide.

(1)The relationship between smart pickup box service quality , perceived ease of use and perceived usefulness

Shiwei validated three dimensions of perceived interaction (information quality, system quality and service quality) could positively affect perceived usefulness and perceived ease of use ${ }^{[3]}$,Yang Ying found that quality of website(delivery quality, system quality, information quality and service quality)could positively affect perceived usefulness and ease of use of the website ${ }^{\text {[4] }}$. Based on the above, the following hypotheses are defined:

H1: smart pickup box service quality positively affects perceived ease of use. H1a: convenience positively affects perceived ease of use. H1b: diversity positively affects perceived ease of use. H1c: responsiveness positively affects perceived ease of use.

H2: smart pickup box service quality positively affects perceived usefulness. H2a:convenience positively affects perceived usefulness. H2b: diversity positively affects perceived usefulness. H2c:responsiveness positively affects Perceived usefulness.

(2)The relationship between smart pickup box service quality and customer's use intention

Boshoff and Gray studied the relationship between the customer perceived service quality, customer satisfaction, and use intention, found service quality positively affects customer satisfaction and use intention ${ }^{[5]}$.Olorunniwo and Hsu proved that the perceived service quality can not only improve customer satisfaction, but also positively affect the behavior intention of customers ${ }^{[6]}$. Based on the above, The hypotheses have the following form:

H3: smart pickup box service quality positively affects customer's use intention. H3a: convenience positively affects customer use intention. H3b: diversity positively affects customer use intention. H3c: responsiveness positively affects customer use intention.

(3)The relationship between perceived usefulness, perceived ease of use and customer's use intention

It can be seen from the literature review that Davis showed perceived usefulness and perceived ease of use positively affected use intention in TAM, perceived ease of use affected perceived usefulness. Most literatures have confirmed that perceived ease of use positively affects customer's use intention and perceived usefulness, such as Pagani ${ }^{[7]}$, Joo ${ }^{[8]}$ and Hamid ${ }^{[9]}$. Based on the above, the paper sets the following hypotheses :

H4: perceived usefulness positively affects customer use intention. H5: perceived ease of use positively affects customer use intention. H6: perceived ease of use positively affects perceived usefulness.

\section{B. Model construction}

Based on the TAM and the above hypotheses, the paper constructs the theoretical model of smart pickup box service quality and customer's use intention.

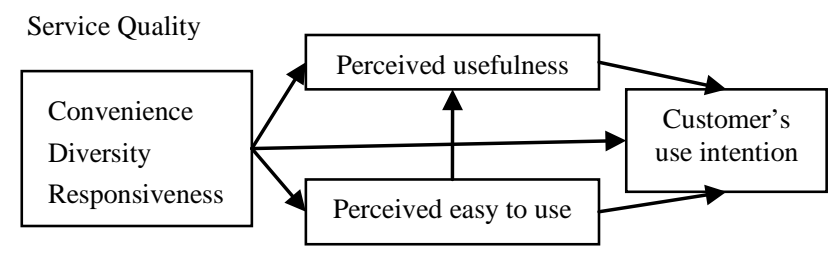

Fig. 2. The model of service quality and customer's use intention

\section{DATA COLLECTION AND ANALYSIS}

\section{A. Data collection}

The survey questionnaire method was used for data collection , we conducted a survey at schools, various districts, office buildings and other places. The main part of the questionnaire includes 18 items, the survey questionnaire uses the Likert five-scales to assess each item. Out of 300 sent questionnaires,280 questionnaires are filled,265 questionnaires are valid, the effective rate is $94.6 \%$.

\section{B. Validity and Reliability analysis}

\section{1) validity analysis}

In this paper, the validity of the questionnaire is tested by factor analysis. Before the factor analysis, we need to test the Bartlett's test of Sphericity and KMO of the data to judge whether it is suitable for factor analysis. The KMO of the data is 0.927, which is higher than 0.7; the Bartlett's test of Sphericity is 0.00 , which is lower than 0.01 , indicating that the data is suitable for factor analysis.

This paper uses factor analysis to extract common factor from selected data, the result shows six common factors(convenience, diversity, responsiveness, perceived ease of use, perceived usefulness, use intention) are successfully extracted from the data, which is consistent with the questionnaire, indicating that the design of the questionnaire can pass the validity test.

\section{2) Reliability analysis}

The reliability of the questionnaire is tested by the Cronbach's alpha, whose value is from 0.809 to 0.941 . these values exceed 0.7 . The questionnaire passes the reliability test , which shows that the indicators within the questionnaire have good internal consistency (as shown in Table I).

TABLE I. THE RELIABILITY RESULTS OF THE SCALE

\begin{tabular}{|c|c|c|}
\hline Scale name & Number of items & Cronbach's alpha \\
\hline Convenience & 3 & 0.822 \\
\hline Diversity & 3 & 0.809 \\
\hline Responsiveness & 3 & 0.857 \\
\hline perceived ease of use & 3 & 0.941 \\
\hline perceived usefulness & 3 & 0.873 \\
\hline use intention & 3 & 0.932 \\
\hline
\end{tabular}




\section{C. hypotheses verification}

The paper takes three dimensions of the service quality as independent variables; perceived ease of use, perceived usefulness and customer's use intention as dependent variables for multiple regression analysis. Meanwhile the relationship between perceived ease of use, perceived usefulness and use intention are verified by the simple regression analysis. The analysis results are shown in the following table.

TABLE II. THE ANALYSIS RESUlT OF THE EFFECT OF THREE DIMENSIONS OF SERVICE QUALITY ON PERCEIVED EASE OF USE

\begin{tabular}{|c|c|c|c|c|c|c|}
\hline \multirow{2}{*}{$\begin{array}{c}\text { Independent } \\
\text { variable }\end{array}$} & \multirow{2}{*}{ constant } & \multicolumn{2}{|c|}{$\begin{array}{c}\text { Non - normalized } \\
\text { coefficients }\end{array}$} & $\begin{array}{c}\text { normalized } \\
\text { coefficients }\end{array}$ & \multirow{2}{*}{ T } & \multirow{2}{*}{ sig. } \\
\cline { 4 - 6 } & & $\mathbf{B}$ & $\begin{array}{c}\text { Standard } \\
\text { error }\end{array}$ & Beta & & \\
\cline { 1 - 5 } Convenience & & .460 & .091 & .429 & 5.047 & .000 \\
\cline { 1 - 5 } Diversity & \multirow{2}{*}{4.217} & .241 & .091 & .226 & 2.665 & .009 \\
\cline { 3 - 7 } Responsiveness & & .050 & .102 & .043 & .484 & .629 \\
\hline
\end{tabular}

It can be seen from Table II that the influence coefficient of convenience on perceived ease of use is $0.429(p=0.00$ $<0.05), \mathrm{H} 1 \mathrm{a}$ is valid; the influence coefficient of diversity on perceived ease of use is 0.226 ( $p=0.009<0.05)$, H1b is valid; the influence coefficient of responsiveness on perceived ease of use is $0.043(\mathrm{p}=0.629>0.05), \mathrm{H} 1 \mathrm{c}$ is not valid. According to the above analysis, the effect of convenience on perceived ease of use is the biggest in three dimensions of the service quality, which indicates that simple operation process and wide coverage have the greatest impact on perceived ease of use.

TABLE III. THE ANALYSIS RESUlT OF THE EFFECT OF THREE DIMENSIONS OF SERVICE QUALITY ON PERCEIVED USEFULNESS

\begin{tabular}{|c|c|c|c|c|c|c|}
\hline \multirow{2}{*}{$\begin{array}{c}\text { Independent } \\
\text { variable }\end{array}$} & \multirow{2}{*}{ constant } & \multicolumn{2}{|c|}{$\begin{array}{l}\text { Non - normalized } \\
\text { coefficients }\end{array}$} & \multirow{2}{*}{$\begin{array}{c}\text { normalized } \\
\text { coefficients } \\
\text { Beta }\end{array}$} & \multirow{2}{*}{$\mathbf{T}$} & \multirow{2}{*}{ sig. } \\
\hline & & B & $\begin{array}{c}\text { Standard } \\
\text { error }\end{array}$ & & & \\
\hline Convenience & \multirow{3}{*}{3.592} & .427 & .077 & .432 & 5.522 & .000 \\
\hline Diversity & & .143 & .077 & .145 & 1.860 & .065 \\
\hline Responsiveness & & .226 & .087 & .213 & 2.601 & .010 \\
\hline
\end{tabular}

Table III shows that the influence coefficient of convenience on perceived usefulness is $0.432(\mathrm{p}=0.000$ $<0.05), \mathrm{H} 2 \mathrm{a}$ is valid; the influence coefficient of diversity on perceived usefulness is $0.145(\mathrm{p}=0.065>0.05), \mathrm{H} 2 \mathrm{~b}$ is not valid; the influence coefficient of responsiveness on perceived usefulness is 0.213 ( $\mathrm{p}=0.01<0.05$ ), H2c is valid. According to the above analysis, customers are more concerned with the convenience in terms of perceived usefulness, functional diversity has little effect on perceived usefulness.
TABLE IV. THE ANALYSIS RESUlt OF THE EFFECT OF THREE DIMENSIONS OF SERVICE QUALITY ON CUSTOMER'S USE INTENTION

\begin{tabular}{|c|c|c|c|c|c|c|}
\hline \multirow{2}{*}{$\begin{array}{c}\text { Independent } \\
\text { variable }\end{array}$} & \multirow{2}{*}{ constant } & \multicolumn{2}{|c|}{$\begin{array}{l}\text { Non - normalized } \\
\text { coefficients }\end{array}$} & \multirow{2}{*}{$\begin{array}{c}\begin{array}{c}\text { normalized } \\
\text { coefficients }\end{array} \\
\text { Beta }\end{array}$} & \multirow{2}{*}{$\mathbf{T}$} & \multirow{2}{*}{ sig. } \\
\hline & & B & $\begin{array}{c}\text { Standard } \\
\text { error }\end{array}$ & & & \\
\hline Convenience & \multirow{3}{*}{2.832} & .501 & .082 & .472 & 6.141 & .000 \\
\hline Diversity & & .106 & .081 & .100 & 1.311 & .192 \\
\hline Responsiveness & & .254 & .092 & .223 & 2.767 & .006 \\
\hline
\end{tabular}

Table IV shows the influence coefficient of convenience on use intention is 0.472 ( $p=0.00<0.05$ ), H3a is valid; the influence coefficient of diversity on use intention is 0.100 (p $=0.192>0.05$ ), H3b is not valid; The influence coefficient of responsiveness on use intention is $0.223(\mathrm{p}=0.006<0.05$ ), $\mathrm{H3c}$ is valid. According to the above result, the convenience has the greatest effect on customer's use intention, indicating customers are more concerned about the convenience ,when consider whether or not to use the smart pickup box service.

TABLE V. THE ANALYSIS RESULT OF THE EFFECT OF PERCEIVED EASE OF USE AND PERCEIVED USEFULNESS ON CUSTOMER'S USE INTENTION

\begin{tabular}{|c|c|c|c|c|c|c|}
\hline \multirow{2}{*}{$\begin{array}{c}\text { Independent } \\
\text { variable }\end{array}$} & \multirow{2}{*}{ constant } & \multicolumn{2}{|c|}{$\begin{array}{c}\text { Non - normalized } \\
\text { coefficients }\end{array}$} & \multirow{2}{*}{$\begin{array}{c}\text { normalized } \\
\text { coefficients } \\
\text { Beta }\end{array}$} & \multirow{2}{*}{$\mathbf{T}$} & \multirow{2}{*}{ sig. } \\
\hline & & B & $\begin{array}{c}\text { Standard } \\
\text { error }\end{array}$ & & & \\
\hline PEOU & \multirow{2}{*}{.541} & .331 & .068 & .334 & 4.877 & .000 \\
\hline PU & & .605 & .074 & .563 & 8.217 & .000 \\
\hline
\end{tabular}

Table $\mathrm{V}$ shows the significance probability of perceived ease of use and perceived usefulness is less than $0.05, \mathrm{H} 4$ and $\mathrm{H} 5$ are valid, indicating that perceived ease of use and perceived usefulness positively affect customer's use intention. the influence coefficient of perceived ease of use is 0.334 slightly lower than 0.563 of perceived usefulness, therefore perceived ease of use has less effect on use intention than perceived usefulness.

TABLE VI. THE ANALYSIS RESULT OF THE EFFECT OF PERCEIVED EASE OF USE ON PERCEIVED USEFULNESS

\begin{tabular}{|c|c|c|c|c|c|c|}
\hline \multirow{2}{*}{$\begin{array}{c}\text { Independe } \\
\text { nt variable }\end{array}$} & \multirow{2}{*}{ constant } & \multicolumn{2}{|c|}{$\begin{array}{c}\text { Non - normalized } \\
\text { coefficients }\end{array}$} & $\begin{array}{c}\text { normalized } \\
\text { coefficients }\end{array}$ & \multirow{2}{*}{$\mathbf{T}$} & sig. \\
\cline { 3 - 7 } & & $\boldsymbol{B}$ & $\begin{array}{c}\text { Standard } \\
\text { error }\end{array}$ & Beta & & \\
\hline PEOU & 3.023 & .720 & .047 & .782 & 15.457 & .000 \\
\hline
\end{tabular}

Table VI shows that the significance probability is less than 0.05 , H6 is valid. The influence coefficient of perceived ease of use positively on perceived usefulness is 0.782 , 
indicating that perceived ease of use has a high effect on perceived usefulness.

\section{The revised theoretical model}

Based on the above analysis, it is known that $\mathrm{H} 1 \mathrm{a}, \mathrm{H} 1 \mathrm{~b}$, $\mathrm{H} 2 \mathrm{a}, \mathrm{H} 2 \mathrm{c}, \mathrm{H} 3 \mathrm{a}, \mathrm{H} 3 \mathrm{c}, \mathrm{H} 4, \mathrm{H} 5, \mathrm{H} 6$ are verified, H1c, H2b and H3b are overturned. the revised model is obtained, as shown in Fig.3.

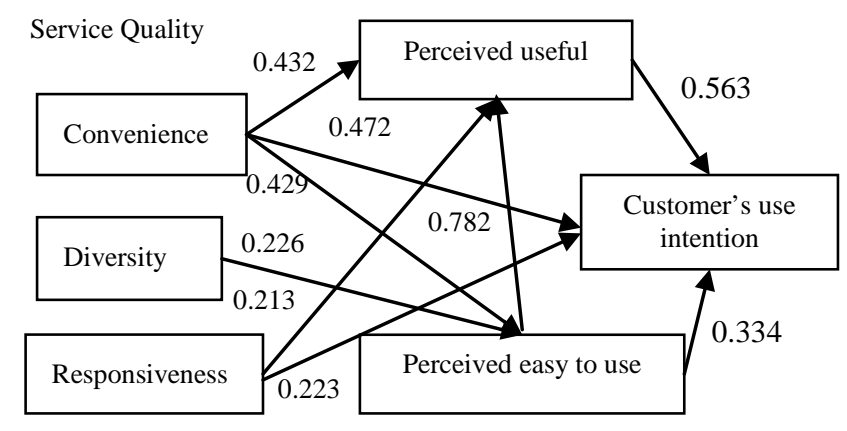

Fig. 3. Revised theoretical model

\section{CONCLUSIONS}

This paper builds the model of smart pickup box service quality and customer 's use intention, The service quality is divided into three dimensions: convenience, diversity and responsiveness. The research sample comprises of the users of the smart express box service, multiple regression analysis is used to test the relationship between three dimensions of service quality, perceived ease of use, perceived usefulness, and customer's use intention.

The results show that convenience has the greatest effect on perceived ease of use, perceived usefulness and customer's use intention in three dimensions of service quality; diversity only positively affects perceived ease of use, has little effect on perceived usefulness and customer's use intention; responsiveness positively affects perceived usefulness and customer 's use intention, has no effect on perceived ease of use; perceived usefulness and perceived ease of use have significant effect on the customer 's use intention; perceived ease of use positively affects perceived usefulness.
On the basis of the above results, we can see that convenience has the greatest effect on the customer's use intention in three dimensions of service quality. Therefore, improving the service quality of smart pickup box ought to focus on convenience, which is helpful to improve customer's use intention, so that smart pickup box can be extensively applied among consumers. For the express companies, the widespread use of the smart pickup box will help solve the "last mile" problem, reduce distribution costs, improve the distribution efficiency and speed up the development of express companies.

\section{REFERENCES}

[1] SHI Guo-hong, HU Xin-yue.Experimental Study on the Predicate and Result of Perceived Service Quality of Mobile Library [J]. Information Theory and Practice, 2015, 38(10):104-109.

[2] Huang Hao. Study on the Change of Adoption Factors of Mobile Content Service Based on TAM and Trust [J]. Economics and Management Review, 2016(4):60-66.

[3] Shi Wei. The Impact of Perceived interactivity on Customer Attitude Based on TAM Theory — Taking Cosmetics Websites as Examples [D]. Dong hua University, 2015.

[4] Yang Ying. Experimental Study of fresh Agricultural Factors Affecting Online Shopping wishes[D]. Anhui University of Finance and Economics, 2014.

[5] Boshoff C, Gray B. The Relationship Between Service Quality, Customer Satisfaction and Buying Intentions in the Private Hospital Industry[J]. South African Journal of Business Management, 2004, 35(4):27-37.

[6] Olorunniwo F, Hsu M K. A typology analysis of service quality, customer satisfaction and behavioral intentions in mass services[J]. Journal of Service Theory \& Practice, 2012, 16(2):106-123.

[7] Pagani M. Determinants of adoption of third generation mobile multimedia services[J]. Journal of Interactive Marketing, 2004, 18(3):46-59.

[8] Joo Y J, Yu H, Lim E. Structural Relationships among Technology Readiness, Perceived Usefulness, Ease of Use, Playfulness and Intention to Use e-Learning[J]. 2016, 47(2):53.

[9] Hamid A A, Razak F Z A, Bakar A A, et al. The Effects of Perceived Usefulness and Perceived Ease of Use on Continuance Intention to Use E-Government [J]. Procedia Economics \& Finance, 2016, 35:644-649. 